\title{
Gracilibacillus ureilyticus sp. nov., a halotolerant bacterium from a saline-alkaline soil
}

\author{
Correspondence \\ Min Wu \\ wumin@zju.edu.cn
}

\author{
Ying-Yi Huo, ${ }^{1}$ Xue-Wei $\mathrm{Xu}^{2,3}$ Heng-Lin $\mathrm{Cui}^{4}$ and $\mathrm{Min} \mathrm{Wu}^{1}$ \\ ${ }^{1}$ College of Life Sciences, Zhejiang University, Hangzhou 310058, PR China \\ ${ }^{2}$ Laboratory of Marine Ecosystem and Biogeochemistry, State Oceanic Administration, Hangzhou \\ 310012, PR China \\ ${ }^{3}$ Second Institute of Oceanography, State Oceanic Administration, Hangzhou 310012, PR China \\ ${ }^{4}$ School of Food and Biological Engineering, Jiangsu University, Zhenjiang 212013, PR China
}

A Gram-stain-positive, halotolerant, neutrophilic, rod-shaped bacterium, strain MF38 ${ }^{\top}$, was isolated from a saline-alkaline soil in China and subjected to a polyphasic taxonomic characterization. The isolate grew in the presence of $0-15 \%(\mathrm{w} / \mathrm{v}) \mathrm{NaCl}$ and at $\mathrm{pH} 6.5-8.5$; optimum growth was observed with $3.0 \%(\mathrm{w} / \mathrm{v}) \mathrm{NaCl}$ and at $\mathrm{pH}$ 7.0. Chemotaxonomic analysis showed menaquinone MK-7 as the predominant respiratory quinone and anteiso- $\mathrm{C}_{15}$ :0, anteiso$\mathrm{C}_{17: 0}$, iso- $\mathrm{C}_{15: 0}, \mathrm{C}_{17: 0}$ and $\mathrm{C}_{16: 0}$ as major fatty acids. The genomic DNA $\mathrm{G}+\mathrm{C}$ content was $35.3 \mathrm{~mol} \%$. 16S rRNA gene sequence similarities of strain MF38 ${ }^{\top}$ with type strains of described Gracilibacillus species ranged from 95.3 to $97.7 \%$. Strain MF38 ${ }^{\top}$ exhibited the closest phylogenetic affinity to the type strain of Gracilibacillus dipsosauri, with $97.7 \% 16$ S rRNA gene sequence similarity. The DNA-DNA reassociation between strain $\mathrm{MF}^{\mathrm{T}}{ }^{\top}$ and $\mathrm{G}$. dipsosauri DSM $11125^{\top}$ was $45 \%$. On the basis of phenotypic and genotypic data, strain MF38 ${ }^{\top}$ represents a novel species of the genus Gracilibacillus, for which the name Gracilibacillus ureilyticus sp. nov. (type strain MF38 ${ }^{\top}=$ CGMCC $1.7727^{\top}=J C M 15711^{\top}$ ) is proposed.
The genus Gracilibacillus was first proposed by Wainø et al. (1999) with the type species Gracilibacillus halotolerans, and Bacillus dipsosauri (Lawson et al., 1996) was reclassified in the genus as Gracilibacillus dipsosauri at the same time. Seven further species, Gracilibacillus orientalis (Carrasco et al., 2006), G. boraciitolerans (Ahmed et al., 2007), G. lacisalsi (Jeon et al., 2008), G. halophilus (Chen et al., 2008a), G. quinghaiensis (Chen et al., 2008b), G. saliphilus (Tang et al., 2009) and G. thailandensis (Chamroensaksri et al., 2010), have since been described. Most of them were isolated from saline lakes, the exceptions being $G$. dipsosauri (from a desert iguana; Lawson et al., 1996), G. boraciitolerans (from a soil containing high levels of boron; Ahmed et al., 2007) and G. thailandensis (from fermented fish; Chamroensaksri et al., 2010). Here, we present the results of a polyphasic study describing a novel halotolerant

\footnotetext{
The GenBank/EMBL/DDBJ accession number for the 16S rRNA gene sequence of strain MF38 ${ }^{\top}$ is EU709020.

Tables comparing the taxonomic characteristics of strain MF38 ${ }^{\top}$ and type strains of related Gracilibacillus species and the cellular fatty acid compositions of strain MF38 ${ }^{\top}$ and G. dipsosauri DSM $11125^{\top}$, an

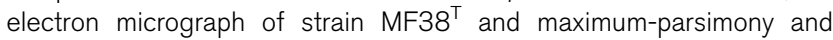
maximum-likelihood 16S rRNA gene sequence-based phylogenetic trees are available as supplementary material with the online version of this paper.
}

Gracilibacillus strain isolated from a saline-alkaline soil in China.

The saline-alkaline soil sample was collected from Minfeng country located in Xinjiang Province, China, in December 2005. The sample contained some granulated salts and was alkaline ( $\mathrm{pH}$ 8.5). Approximately $100 \mathrm{mg}$ soil sample was incubated for $30 \mathrm{~min}$ in modified halophilic medium (HM) containing $10 \% \mathrm{NaCl}(\mathrm{w} / \mathrm{v})$ without carbon source. The modified HM medium contained (per 1 distilled water): $\mathrm{NaCl}$ as indicated, $2.0 \mathrm{~g} \mathrm{KCl}, 1.0 \mathrm{~g} \mathrm{MgSO}_{4}, 0.36 \mathrm{~g}$ $\mathrm{CaCl}_{2} .2 \mathrm{H}_{2} \mathrm{O}, 0.23 \mathrm{~g} \mathrm{NaBr}, 0.06 \mathrm{~g} \mathrm{NaHCO}$, trace $\mathrm{FeCl}_{3}$, $1.0 \mathrm{~g}$ yeast extract (Difco), $0.5 \mathrm{~g}$ peptone (Difco) and $0.1 \mathrm{~g}$ glucose (pH 7.5) (Ventosa et al., 1982). The liquid was plated on modified HM agar plates, using a tenfold dilution series. After 3 days of incubation at $25{ }^{\circ} \mathrm{C}$, a cream-coloured colony, designated $\mathrm{MF} 38^{\mathrm{T}}$, was picked. The strain was purified by repeated restreaking; purity was confirmed by the uniformity of colony morphology.

The 16S rRNA gene was amplified and PCR products were cloned into pMD 19-T vector (TaKaRa) for sequencing (Xu et al., 2007b). An almost-complete 16S rRNA gene sequence (1485 nt) was obtained and compared with closely related sequences of reference organisms from the FASTA and EzTaxon services (Chun et al., 2007). Sequence data were aligned with CLUSTAL W 1.8 (Thompson et al., 1994). 
Phylogenetic trees were constructed by the neighbourjoining (Saitou \& Nei, 1987) and maximum-parsimony (Fitch, 1971) methods with the MEGA 4 program package (Tamura et al., 2007) and the maximum-likelihood method (Felsenstein, 1981) with the TreePuzzle 5.2 program. Evolutionary distances were calculated according to the algorithm of Kimura's two-parameter model (Kimura, 1980) for the neighbour-joining method.

Comparisons of $16 \mathrm{~S}$ rRNA gene sequences showed that

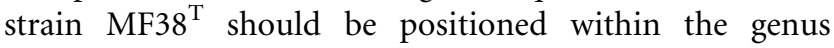
Gracilibacillus, related most closely to the type strain of $G$. dipsosauri, with $97.7 \%$ similarity. Phylogenetic analysis based on 16S rRNA gene sequence showed that strain $M F 38^{\mathrm{T}}$ had the closest phylogenetic affinity to the type strain of G. dipsosauri, with high levels of bootstrap support (Fig. 1). The topologies of phylogenetic trees built using the maximum-parsimony and maximum-likelihood algorithms also supported the notion that strain $\mathrm{MF}^{2} 8^{\mathrm{T}}$ formed a stable clade with $G$. dipsosauri (Supplementary Figs S1 and S2, available in IJSEM Online).

Growth at various $\mathrm{NaCl}$ concentrations $(0,0.5,1.0,2.0,3.0$, 5.0, 7.5, 10.0, 12.5, 15.0, 17.5, 20.0, 22.5 and $25.0 \%$, w/v) was investigated in trypticase soy broth (TSB; Difco) with $1 \mathrm{M} \mathrm{KCl}$ according to Lawson et al. (1996). The $\mathrm{pH}$ range for growth was determined at $\mathrm{pH}$ 5.0-10.0 (at intervals of $0.5 \mathrm{pH}$ units) in TSB with $1 \mathrm{M} \mathrm{KCl}$ using the following buffers at $40 \mathrm{mM}$ : MES (pH 5.0-6.0), PIPES (pH 6.5-7.0), Tricine (pH 7.5-8.5) and CAPSO (pH 9.0-10.0). The temperature range for growth was determined by incubation at $4,10,15,20,25,30,35,37,42,45,48$ and $50{ }^{\circ} \mathrm{C}$. Cell morphology and motility were examined by optical microscopy (BX40; Olympus) and transmission electron microscopy (JEM-1230; JEOL). The $\mathrm{NaCl}$ concentration, $\mathrm{pH}$ and temperature for growth of strain $\mathrm{MF}^{\mathrm{T}} 8^{\mathrm{T}}$ were 0-15\% (w/v), pH 6.5-8.5 and $10-45{ }^{\circ} \mathrm{C}$. Cells of strain $\mathrm{MF} 38^{\mathrm{T}}$ were Gram-stain-positive, spore-forming rods and motile by means of peritrichous flagella (Supplementary Fig. S3).

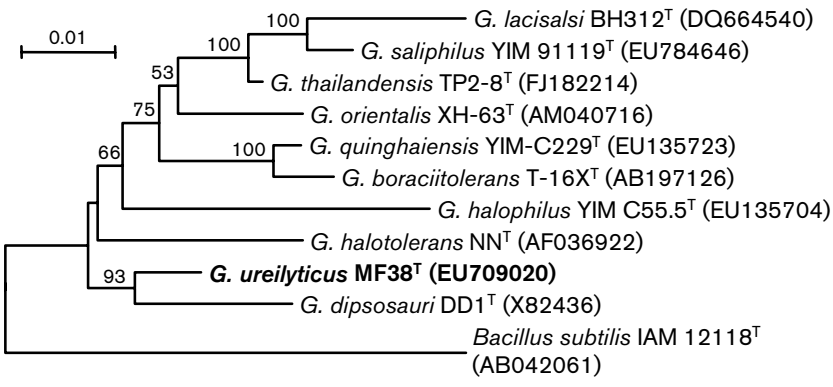

Fig. 1. Neighbour-joining tree based on 16S rRNA gene sequences, showing the phylogenetic relationships of strain MF38 $^{\top}$ and related taxa. Bootstrap values are based on 1000 replicates; values $>50 \%$ are shown. Bar, 0.01 substitutions per nucleotide position.
Single carbon source assimilation tests were performed using modified basal medium $\left[1^{-1}\right.$ distilled water: $1.0 \mathrm{~g}$ $\mathrm{NH}_{4} \mathrm{Cl}, 0.044 \mathrm{~g} \mathrm{~K}_{2} \mathrm{HPO}_{4}, 0.028 \mathrm{~g} \mathrm{FeSO}$. $7 \mathrm{H}_{2} \mathrm{O}, 500 \mathrm{ml}$ artificial seawater, $50 \mathrm{ml}$ Tris/ $\mathrm{HCl} \quad(1 \mathrm{M}, \quad \mathrm{pH}$ 7.5)]. Artificial seawater contained (per 1 distilled water) $30.0 \mathrm{~g}$ $\mathrm{NaCl}, 24.6 \mathrm{~g} \mathrm{MgSO}_{4} .7 \mathrm{H}_{2} \mathrm{O}, 1.5 \mathrm{~g} \mathrm{KCl}$ and $2.9 \mathrm{~g} \mathrm{CaCl}_{2}$. Filter-sterilized sugars $(0.2 \%)$, alcohols $(0.2 \%)$, organic acids $(0.1 \%)$ and amino acids $(0.1 \%)$ were separately added to the liquid medium. Acid production was investigated by using modified MOF medium [per 1 distilled water: $30.0 \mathrm{~g} \mathrm{NaCl}, 2.5 \mathrm{~g} \mathrm{MgCl}_{2} .2 \mathrm{H}_{2} \mathrm{O}, 1.0 \mathrm{~g}$ $\mathrm{MgSO}_{4} .7 \mathrm{H}_{2} \mathrm{O}, 0.5 \mathrm{~g} \mathrm{KCl}, 0.25 \mathrm{~g} \mathrm{CaCl}_{2}$, trace $\mathrm{FeSO}_{4}, 0.5 \mathrm{~g}$ $\left(\mathrm{NH}_{4}\right)_{2} \mathrm{SO}_{4}, 1.0 \mathrm{~g}$ casitone (Difco), $0.1 \mathrm{~g}$ yeast extract (Difco), $0.5 \mathrm{~g}$ Tris base, $0.01 \mathrm{~g}$ phenol red ( $\mathrm{pH} 7.5)]$ supplemented with $1 \%$ sugars or alcohols (Leifson, 1963). Oxidase activity was determined by oxidation of $1 \% p$-aminodimethylaniline oxalate. Catalase activity was determined by bubble production in $3 \%(\mathrm{v} / \mathrm{v}) \mathrm{H}_{2} \mathrm{O}_{2}$ solution. Biochemical and nutritional tests were performed in the modified basal medium supplemented with $5 \mathrm{~g}$ yeast extract $1^{-1}$ according to Mata et al. (2002). Additional enzyme activities and biochemical characteristics were determined using API 20E, API 20NE and API ZYM kits (bioMérieux); cells for inoculation of these API test strips were suspended in $3 \% \mathrm{NaCl}$. API ZYM strips were read after $10 \mathrm{~h}$ and API 20NE and API 20E strips after 24 and 48 h. G. dipsosauri DSM $11125^{\mathrm{T}}$ was used as control in the

Table 1. Differentiating characteristics of strain $M F 38^{\top}$ from its closest phylogenetic relative, G. dipsosauri DSM $11125^{\top}$

Unless indicated, data were obtained in this study under identical growth conditions. + , Positive; - , negative; w, weakly positive.

\begin{tabular}{|c|c|c|}
\hline Characteristic & $\begin{array}{l}\text { Strain } \\
\text { MF38 }^{\mathrm{T}}\end{array}$ & $\begin{array}{l}\text { G. dipsosauri } \\
\text { DSM } 11125^{\mathrm{T}}\end{array}$ \\
\hline Hydrolysis of urea & + & - \\
\hline \multicolumn{3}{|l|}{ Susceptibility to: } \\
\hline Amoxicillin $(10 \mu \mathrm{g})$ & + & - \\
\hline Ampicillin $(10 \mu \mathrm{g})$ & + & - \\
\hline Bacitracin (0.04 IU) & + & - \\
\hline Penicillin G (10 IU) & + & - \\
\hline \multicolumn{3}{|l|}{ API ZYM tests } \\
\hline$\alpha$-Galactosidase & + & - \\
\hline$\beta$-Galactosidase & + & $\mathrm{w}$ \\
\hline$\beta$-Glucosidase & + & $\mathrm{w}$ \\
\hline \multicolumn{3}{|l|}{ Fermentation/oxidation of: } \\
\hline D-Glucose & - & + \\
\hline D-Mannitol & - & + \\
\hline L-Rhamnose & - & + \\
\hline Sucrose & - & + \\
\hline Melibiose & - & + \\
\hline Amygdalin & - & + \\
\hline L-Arabinose & - & + \\
\hline DNA G $+C$ content $(\mathrm{mol} \%)$ & 35.3 & $39.4^{*}$ \\
\hline
\end{tabular}

${ }^{\star}$ Data from Lawson et al. (1996). 
tests. Detailed results are given in the species description and in Table 1 and Supplementary Table S1.

Fatty acid methyl esters obtained from cells grown on MA (Difco) for 2 days at $35{ }^{\circ} \mathrm{C}$ were analysed by using GC/MS (Kuykendall et al., 1988). Isoprenoid quinones were analysed using reversed-phase HPLC as described previously (Komagata \& Suzuki, 1987). Phospholipids and glycolipids were separated on silica gel plates $(10 \times 10 \mathrm{~cm})$ by TLC and were analysed according to Xu et al. (2007a). The purified DNA was hydrolysed with P1 nuclease and the nucleotides were dephosphorylated with calf intestine alkaline phosphatase; the $\mathrm{G}+\mathrm{C}$ content of the resulting deoxyribonucleosides was determined by reversed-phase HPLC and calculated from the ratio of deoxyguanosine (dG) and thymidine (dT) (Mesbah \& Whitman, 1989). The major fatty acids of strain $M F 38^{\mathrm{T}}$ were anteiso- $\mathrm{C}_{15: 0}$ $(34.2 \%)$, anteiso- $C_{17: 0}(21.4 \%)$, iso- $C_{15: 0}(13.7 \%), C_{17: 0}$ (7.0\%) and $\mathrm{C}_{16: 0}(6.2 \%)$. This profile is similar to that of G. dipsosauri DSM $11125^{\mathrm{T}}$. Nevertheless, the absence of $\mathrm{C}_{12: 0}$, iso- $\mathrm{C}_{13: 0}$, iso- $\mathrm{C}_{18: 0}, \mathrm{C}_{18: 1} \omega 9 c, \mathrm{C}_{19: 0}$ and anteiso$\mathrm{C}_{19: 0}$ from the fatty acids is a distinct characteristic that differentiates strain MF38 ${ }^{\mathrm{T}}$ from G. dipsosauri DSM $11125^{\mathrm{T}}$ (Supplementary Table S2).

Strain $M F 38^{\mathrm{T}}$ exhibited the closest phylogenetic affinity and highest $16 \mathrm{~S}$ rRNA gene sequence similarity to $G$. dipsosauri DSM $11125^{\mathrm{T}}$. DNA-DNA hybridizations were performed by the thermal denaturation and renaturation method of De Ley et al. (1970) as modified by Huß et al. (1983), using a Beckman DU 800 spectrophotometer. The level of DNA-DNA relatedness of $45 \%$ between strain MF $38^{\mathrm{T}}$ and G. dipsosauri DSM $11125^{\mathrm{T}}$ is significantly below the value of $70 \%$ considered to be the threshold for the delineation of bacterial species (Wayne et al., 1987). In addition, strain $M F 38^{\mathrm{T}}$ could be differentiated from recognized species on the basis of some phenotypic characteristics, including spore shape, nitrate reduction, $\mathrm{H}_{2} \mathrm{~S}$ production, hydrolysis of substrates, susceptibility to antibiotics and enzyme activities (Supplementary Table S1). Strain $\mathrm{MF}^{\mathrm{T}}{ }^{\mathrm{T}}$ could also be distinguished from $G$. dipsosauri DSM $11125^{\mathrm{T}}$ by several phenotypic characteristics, including hydrolysis of urea, $\alpha$-galactosidase activity, susceptibility to bacitracin and penicillin $\mathrm{G}$ and fermentation of sugars (Table 1).

On the basis of the phylogenetic, genotypic, chemotaxonomic and phenotypic data, we propose to classify strain $M F 38^{\mathrm{T}}$ as the type strain of a novel species within the genus Gracilibacillus, Gracilibacillus ureilyticus sp. nov.

\section{Description of Gracilibacillus ureilyticus sp. nov.}

Gracilibacillus ureilyticus (u.re.i.ly'ti.cus. N.L. n. urea urea; N.L. adj. lyticus able to dissolve; N.L. masc. adj. ureilyticus urea-dissolving).

Cells are Gram-stain-positive, spore-forming, motile rods, $0.7-1.0 \mu \mathrm{m}$ wide and $1.5-4.5 \mu \mathrm{m}$ long. Colonies on MA are $1-2 \mathrm{~mm}$ in diameter, rough, slightly elevated and cream- coloured with irregular edges after 2 days at $37{ }^{\circ} \mathrm{C}$. Growth occurs at $\mathrm{NaCl}$ concentrations of $0-15 \%(\mathrm{w} / \mathrm{v})$, with optimum growth at $3.0 \%$, and at $\mathrm{pH} 6.5-8.5$ and $10-45{ }^{\circ} \mathrm{C}$ (optimum growth at $\mathrm{pH} 7.0$ and $35-37^{\circ} \mathrm{C}$ ). Oxidase- and catalase-positive. Aesculin, gelatin, starch, Tween 20 and urea are hydrolysed. Casein, DNA, Tweens 40, 60 and 80 and tyrosine are not hydrolysed. Arginine dihydrolase, indole production, lysine and ornithine carboxylases, citrate utilization, tryptophan deaminase and fermentation of amygdalin, L-arabinose, D-glucose, inositol, D-mannitol, melibiose, L-rhamnose, D-sorbitol and sucrose are negative. Voges-Proskauer and $o$-nitrophenyl- $\beta$-D-galactopyranosidase tests are positive. Nitrate is reduced to nitrite. $\mathrm{H}_{2} \mathrm{~S}$ is not produced. The following substrates are utilized for growth: L-arabinose, cellobiose, D-galactose, gluconate, glucose, lactose, maltose, D-mannitol, D-mannose, raffinose, L-rhamnose, D-salicin, starch, sucrose, trehalose and D-xylose. The following compounds are not utilized as sole carbon and energy sources: acetate, L-alanine, L-arginine, Lasparagine, L-aspartate, citrate, L-cysteine, ethanol, formate, fumarate, L-glutamate, L-glutamine, glycine, L-histidine, isoleucine, lactate, L-lysine, malate, malonate, Lmethionine, L-ornithine, propionate, pyruvate, ribitol, Lserine, D-sorbitol, L-sorbose, succinate and L-valine. Acid is produced from L-arabinose, cellobiose, D-fructose, Dgalactose, glucose, lactose, maltose, D-mannitol, raffinose, L-rhamnose, D-salicin, starch, sucrose, trehalose and Dxylose, but not from ethanol, ribitol, D-sorbitol or Lsorbose. In the API ZYM system, alkaline phosphatase, esterase (C4), esterase lipase (C8), $\alpha$ - and $\beta$-galactosidase and $\alpha$ - and $\beta$-glucosidase activities are present, whereas acid phosphatase, $\alpha$-chymotrypsin, $N$-acetyl- $\beta$-glucosaminidase, cystine arylamidase, $\beta$-fucosidase, $\beta$-glucuronidase, leucine arylamidase, lipase (C14), $\alpha$-mannosidase, naphthol-AS-BI-phosphohydrolase, trypsin and valine arylamidase activities are absent. Susceptible to discs containing ( $\mu \mathrm{g}$ unless otherwise stated) amoxicillin (10), ampicillin (10), bacitracin (0.04 IU), carbenicillin (100), cefotaxime (30), cefoxitin (30), chloramphenicol (30), erythromycin (15), kanamycin (30), neomycin (30), nitrofurantoin (300), novobiocin (30), penicillin G (10 IU), rifampicin (5), tetracycline (10) and tobramycin (10), but not susceptible to nystatin (100) or streptomycin (10). The predominant menaquinone is MK-7. The major polar lipids include diphosphatidylglycerol, phosphatidylglycerol, three unidentified phospholipids and three glycolipids. The major fatty acids $(>5 \%)$ include anteiso$\mathrm{C}_{15: 0}$, anteiso- $\mathrm{C}_{17: 0}$, iso- $\mathrm{C}_{15: 0}, \mathrm{C}_{17: 0}$ and $\mathrm{C}_{16: 0}$. The DNA $\mathrm{G}+\mathrm{C}$ content of the type strain is $35.3 \mathrm{~mol} \%$.

The type strain, MF38 ${ }^{\mathrm{T}}$ (=CGMCC $1.7727^{\mathrm{T}}=\mathrm{JCM}$ $15711^{\mathrm{T}}$ ), was isolated from a saline-alkaline soil sample from Minfeng county, Xinjiang, China.

\section{Acknowledgements}

We thank Jean Euzéby for his help with the specific etymology and nomenclature. This work was supported by grants from the Ministry 
of Science and Technology of China (973 Program, 2004CB719604-3; 863 Program, 2007AA021305) and the Key Project of Zhejiang Science and Technology (2006C13053).

\section{References}

Ahmed, I., Yokota, A. \& Fujiwara, T. (2007). Gracilibacillus boraciitolerans sp. nov., a highly boron-tolerant and moderately halotolerant bacterium isolated from soil. Int J Syst Evol Microbiol 57, 796-802.

Carrasco, I. J., Márquez, M. C., Yanfen, X., Ma, Y., Cowan, D. A., Jones, B. E., Grant, W. D. \& Ventosa, A. (2006). Gracilibacillus orientalis sp. nov., a novel moderately halophilic bacterium isolated from a salt lake in Inner Mongolia, China. Int J Syst Evol Microbiol 56, 599-604.

Chamroensaksri, N., Tanasupawat, S., Akaracharanya, A., Visessanguan, W., Kudo, T. \& Itoh, T. (2010). Gracilibacillus thailandensis sp. nov., from fermented fish (pla-ra) in Thailand. Int J Syst Evol Microbiol 60, 944-948.

Chen, Y.-G., Cui, X.-L., Zhang, Y.-Q., Li, W.-J., Wang, Y.-X., Xu, L.-H., Peng, O., Wen, M.-L. \& Jiang, C.-L. (2008a). Gracilibacillus halophilus sp. nov., a moderately halophilic bacterium isolated from saline soil. Int J Syst Evol Microbiol 58, 2403-2408.

Chen, Y.-G., Cui, X.-L., Zhang, Y.-Q., Li, W.-J., Wang, Y.-X., Xu, L.-H., Peng, Q., Wen, M.-L. \& Jiang, C.-L. (2008b). Gracilibacillus quinghaiensis sp. nov., isolated from salt-lake sediment in Qaidam Basin, north-west China. Syst Appl Microbiol 31, 183-189.

Chun, J., Lee, J.-H., Jung, Y., Kim, M., Kim, S., Kim, B. K. \& Lim, Y.-W. (2007). EzTaxon: a web-based tool for the identification of prokaryotes based on 16S ribosomal RNA gene sequences. Int J Syst Evol Microbiol 57, 2259-2261.

De Ley, J., Cattoir, H. \& Reynaerts, A. (1970). The quantitative measurement of DNA hybridization from renaturation rates. Eur $J$ Biochem 12, 133-142.

Felsenstein, J. (1981). Evolutionary trees from DNA sequences: a maximum likelihood approach. J Mol Evol 17, 368-376.

Fitch, W. M. (1971). Toward defining the course of evolution: minimum change for a specific tree topology. Syst Zool 20, 406-416.

Huß, V. A. R., Festl, H. \& Schleifer, K. H. (1983). Studies on the spectrophotometric determination of DNA hybridization from renaturation rates. Syst Appl Microbiol 4, 184-192.

Jeon, C. O., Lim, J.-M., Jang, H. H., Park, D.-J., Xu, L.-H., Jiang, C.-L. \& Kim, C.-J. (2008). Gracilibacillus lacisalsi sp. nov., a halophilic Grampositive bacterium from a salt lake in China. Int J Syst Evol Microbiol 58, 2282-2286.

Kimura, M. (1980). A simple method for estimating evolutionary rates of base substitutions through comparative studies of nucleotide sequences. J Mol Evol 16, 111-120.

Komagata, K. \& Suzuki, K. (1987). Lipid and cell-wall analysis in bacterial systematics. Methods Microbiol 19, 161-207.
Kuykendall, L. D., Roy, M. A., O'Neill, J. J. \& Devine, T. E. (1988). Fatty acids, antibiotic resistance, and deoxyribonucleic acid homology groups of Bradyrhizobium japonicum. Int J Syst Bacteriol 38, 358-361.

Lawson, P. A., Deutch, C. E. \& Collins, M. D. (1996). Phylogenetic characterization of a novel salt-tolerant Bacillus species: description of Bacillus dipsosauri sp. nov. J Appl Bacteriol 81, 109-112.

Leifson, E. (1963). Determination of carbohydrate metabolism of marine bacteria. J Bacteriol 85, 1183-1184.

Mata, J. A., Martínez-Cánovas, J., Quesada, E. \& Béjar, V. (2002). A detailed phenotypic characterisation of the type strains of Halomonas species. Syst Appl Microbiol 25, 360-375.

Mesbah, M. \& Whitman, W. B. (1989). Measurement of deoxyguanosine/thymidine ratios in complex mixtures by high-performance liquid chromatography for determination of the mole percentage guanine + cytosine of DNA. J Chromatogr 479, 297-306.

Saitou, N. \& Nei, M. (1987). The neighbor-joining method: a new method for reconstructing phylogenetic trees. Mol Biol Evol 4, 406425.

Tamura, K., Dudley, J., Nei, M. \& Kumar, S. (2007). MEGA4: molecular evolutionary genetics analysis (MEGA) software version 4.0. Mol Biol Evol 24, 1596-1599.

Tang, S.-K., Wang, Y., Lou, K., Mao, P.-H., Jin, X., Jiang, C.-L., Xu, L.-H. \& Li, W.-J. (2009). Gracilibacillus saliphilus sp. nov., a moderately halophilic bacterium isolated from a salt lake. Int J Syst Evol Microbiol 59, 1620-1624.

Thompson, J. D., Higgins, D. G. \& Gibson, T. J. (1994). Clustal W: improving the sensitivity of progressive multiple sequence alignment through sequence weighting, position-specific gap penalties and weight matrix choice. Nucleic Acids Res 22, 4673-4680.

Ventosa, A., Quesada, E., Rodriguez-Valera, F., Ruiz-Berraquero, F. \& Ramos-Cormenzana, A. (1982). Numerical taxonomy of moderately halophilic Gram-negative rods. J Gen Microbiol 128, 1959-1968.

Wainø, M., Tindall, B. J., Schumann, P. \& Ingvorsen, K. (1999). Gracilibacillus gen. nov., with description of Gracilibacillus halotolerans gen. nov., sp. nov.; transfer of Bacillus dipsosauri to Gracilibacillus dipsosauri comb. nov., and Bacillus salexigens to the genus Salibacillus gen. nov., as Salibacillus salexigens comb. nov. Int J Syst Bacteriol 49, 821-831.

Wayne, L. G., Brenner, D. J., Colwell, R. R., Grimont, P. A. D., Kandler, O., Krichevsky, M. I., Moore, L. H., Moore, W. E. C., Murray, R. G. E. \& other authors (1987). International Committee on Systematic Bacteriology. Report of the ad hoc committee on reconciliation of approaches to bacterial systematics. Int J Syst Bacteriol 37, 463-464.

Xu, X.-W., Wu, Y.-H., Wang, C.-S., Oren, A., Zhou, P.-J. \& Wu, M. (2007a). Haloferax larsenii sp. nov., an extremely halophilic archaeon from a solar saltern. Int J Syst Evol Microbiol 57, 717-720.

Xu, X.-W., Wu, Y.-H., Zhou, Z., Wang, C.-S., Zhou, Y.-G., Zhang, H.-B., Wang, Y. \& Wu, M. (2007b). Halomonas saccharevitans sp. nov., Halomonas arcis sp. nov. and Halomonas subterranea sp. nov., halophilic bacteria isolated from hypersaline environments of China. Int J Syst Evol Microbiol 57, 1619-1624. 